\title{
The Relationship between Corporate Governance and Voluntary Disclosure: The Role of Boards of Directors and Audit Committees
}

\author{
Lama Alyousef ${ }^{1}$, Sulaiman Alsughayer,"* \\ ${ }^{1}$ M.S. of Accounting, College of Economics and Administrative Sciences, Imam Mohammad Bin Saud Islamic University, \\ Riyadh, Saudi Arabia \\ ${ }^{2}$ College of Economics and Administrative Sciences, Imam Mohammad Bin Saud Islamic University, Riyadh, Saudi Arabia
}

Received May 27, 2021; Revised July 9, 2021; Accepted July 29, 2021

\begin{abstract}
Cite This Paper in the following Citation Styles
(a): [1] Lama Alyousef, Sulaiman Alsughayer, "The Relationship between Corporate Governance and Voluntary Disclosure: The Role of Boards of Directors and Audit Committees, "Universal Journal of Accounting and Finance, Vol. 9, No. 4, pp. 678-692, 2021. DOI: 10.13189/ujaf.2021.090416
\end{abstract}

(b): Lama Alyousef, Sulaiman Alsughayer (2021). The Relationship between Corporate Governance and Voluntary Disclosure: The Role of Boards of Directors and Audit Committees. Universal Journal of Accounting and Finance, 9(4), 678-692. DOI: 10.13189/ujaf.2021.090416.

Copyright $\bigcirc 2021$ by authors, all rights reserved. Authors agree that this article remains permanently open access under the terms of the Creative Commons Attribution License 4.0 International License

\begin{abstract}
The objective of the present research is to examine the relationship between corporate governance and voluntary disclosure, and to determine how certain factors enhance governance practices and consequently increase voluntary disclosure. The study considers the content analysis of 22 Saudi listed companies from 2015 to 2019. A comprehensive index is developed, with a check-list covering 30 items to extract and measure corporate governance practices and levels of voluntary disclosure. The researchers use ordinary least squares (OLS) regression to examine whether corporate governance-specific mechanisms can explain any differences in voluntary disclosure levels among the listed companies. The results indicate a statistically significant relationship between the number of non-executive directors and board size and the level of voluntary disclosure. This study concluded that non-executive directors and board size are ranked the highest in terms of their positive effects on voluntary disclosure. The relationship between the independent directors and audit committees and voluntary disclosure is insignificant. The results suggest that the high number of non-executive directors and the increase in the number of directors on the boards lead to greater voluntary disclosure of information. This study helps regulators of corporate governance and company directors understand the factors affecting
\end{abstract}

voluntary disclosure. Corporate governance regulators should require an increase in the minimum number of boards and non-executive directors for listed companies in order to gain the desired levels of voluntary disclosure and transparency. Saudi listed companies are advised to willingly increase their board members to the maximum number specified by regulation. This study has some limitations as participants represented a small sample; hence, the results cannot be generalised. Furthermore, the voluntary disclosure data were collected only from annual reports; sources such as websites, public announcements and press releases, were not taken into account, but would have provided many relevant details.

Keywords Voluntary Disclosure (VD), Corporate Governance (CG), Agency Theory, Saudi Arabia (SA)

\section{Introduction}

Financial reporting and disclosure are important tools that management may use to communicate the performance and governance of a firm to outside investors. The quality of voluntary disclosure (VD) included in companies' annual reports is at the heart of modern 
financial reporting. Corporate VD is often a major source of information for capital markets (Frenkel et al., 2020), and it is important for their effective functioning because it increases potential shareholder and investor confidence by clearly communicating corporate governance and performance (Saha \& Kabra, 2020). Thus, more disclosure transparency increases stakeholder's awareness and confidence (Matoussi \& Chakroun, 2008). Investors and other key stakeholders have been dissatisfied by some practices of financial reporting, leading to demands that companies provide more comprehensive voluntary information about their strategies and long-term performance (Kumar, 2007). Additional VD helps investors reduce the likelihood of making uninformed investment decisions by reducing information asymmetries between shareholders and management (Schuster \& O'Connell, 2006).

Recent financial scandals have prompted examinations of the potential relationship between a company's governance and its disclosure practices. Cormier et al. (2010) asserted that it would be very difficult to arrive at a conclusion about the expected failures of companies relying only on mandatory disclosure. Although financial scandals have been reported about well-known companies with many attributes of good governance (including boards of directors and audit committees), information emerging in the wake of their failures reveals that the actual governance processes of these companies were ineffectively dominated by top management, and that their disclosure practices were unsatisfactory. Even though all listed companies are required to meet minimum disclosure requirements, these companies differ in the amount of additional information they chose to disclose to capital markets. One way for a company to improve its credibility is through large-scale VD that enables investors to understand its business strategy and management (Gunawan \& Lina, 2015).

The purpose of the present study is to examine the relationships between corporate governance (CG) and VD, and to determine how certain CG factors and practices lead to increasing such disclosure in nonfinancial listed companies in Saudi Arabia. The researchers developed a number of hypotheses concerning the relationship between CG and VD, focusing on board size, non-executive directors, board independence and audit committee as independent variables, and VD as a dependent variable.

Prior research on VD has analyzed the relationship between the level of VD and different variables, including CG mechanisms, ownership structure and firm-specific characteristics. However, most of these studies were conducted in developed countries in the global east and west, and only a few studies have centered on developing countries, including in Saudi Arabia. Research in Saudi Arabia has not considered the relationship between disclosure and some of the CG mechanisms. The present study fills this gap in the literature by examining a comprehensive set of variables across CG in Saudi listed companies, and by covering a period comparatively longer than those used in previous Saudi studies (Al-Janadi et al., 2013; Al-Moataz \& Hussainey, 2013). A majority of the listed companies have board concentration; hence, it is common for boards to possess considerable control in the management (OECD, 2004). Al-Al-Ghamdi and Rhodes (2015) asserted that such concentration leads to conflicts of interest between the stakeholders and controlling board members. Therefore, it is very important to understand the $\mathrm{CG}$ and the effect of a board's role on disclosure in a given company (Gad, 2020; Hashed \& Almaqtari, 2021).

This study makes several contributions to the general CG literature, as well as to Saudi Arabia's own body of research. Its findings contribute significantly to understanding the current state and issues of CG practices in Saudi Arabia, a vested interest for stakeholders such as regulators, policymakers, academics and the entire community. This type of research helps in identifying some of the determinants of VD in Saudi Arabia as well as in providing information about VD and its relationship to $\mathrm{CG}$.

\section{Literature Review and Hypothesis Development}

\subsection{Corporate Governance (CG)}

CG has become a constant element in academic and policy debates, and the primary business-related preoccupation of our time. Nowadays, CG is an element that shapes as business. Its importance to corporate success as well as to social well-being cannot be overemphasised. Recent publicity around corporate collapses that resulted from weak CG systems have highlighted an international need to improve and reform CG. Researchers have recognised that CG definitions vary widely, ranging from a narrow perspective focusing on companies and their shareholders (i.e. performance, efficiency, growth, financial structure) to broader definitions concerned with the accountability of companies to stakeholders (i.e. rules under which companies operate, derived from sources such as the legal and judicial systems and financial and labour markets (Onakoya et al., 2012). Solomon and Solomon (2004) defined CG as 'the system of checks and balances, both internal and external to companies, which ensures that companies discharge their accountability to all their stakeholders and act in a socially responsible way in all areas of their business activity' (p. 14). Accordingly, CG is the mechanism that protects the interests of shareholders from the inappropriate behaviour of managers in a company (Maskati \& Hamdan, 2017).

CG can be understood as a combination of policies, 
laws and instructions which affect how the company is managed and controlled (Buallay et al., 2017). CG consists of a framework of rules and procedures for facilitating the decision-making process towards achieving fairness, competitiveness and transparency in the relationship between companies and their shareholders. Hashed and Almaqtari (2021) assess the influence of CG mechanisms on financial reporting quality using a sample of 102 Saudi listed companies for the period $2014-2019$. The results indicate that independence of the audit committee from the board showed a significant positive effect on the quality of financial reporting. Agency theory has been the primary basis for the development of $\mathrm{CG}$ standards, principles, and codes and has been used extensively by academics and practitioners and still dominates CG literature to date (Christopher, 2010).

\subsubsection{Agency Theory}

Agency theory states that because of the separation between ownership and control, problems may arise in the relationship between a principal (shareholder) and an agent (corporate manager). Zahra and Pearce (1989) argued that the premise of the agency model assumes or emphasizes a conflict between agent and principal, which becomes important for controlling and monitoring a board's function. Agency theory then attempts to reduce information asymmetries by incorporating monitors (Shapiro, 2005) and establishing mechanisms that can defend shareholders from conflicts of interest on the part of management (Fama \& Jensen, 1983).

According to Mallin (2007), agency theory provides the best explanation for CG roles with respect to ownership and control through the use of internal CG mechanisms. From an agency perspective, boards of directors and audit committees are used as effective monitoring device for protecting shareholder interests (Bonazzi \& Islam, 2007; Eisenhardt, 1989; Shapiro, 2005). The board of directors and the audit committee make up parts of the internal governance mechanisms, because their use depends on internal decision-makers and incorporates four internal variables: board size, structure, composition, and audit committee independence (Khanchel El Mehdi, 2007). In an effort to deal with agency problems, CG literature emphasises the significant role that the board of directors plays in monitoring top management, so as to ensure that managers act in the interests of shareholders. It also emphasises the role of audit committees in monitoring the decision control system (Fama \& Jensen, 1983; Jensen \& Meckling, 1976; Peasnell et al., 2005). Given assumptions of agency theory, enhancing CG mechanisms should result in the reduction of information asymmetry. It is expected that companies with stronger $\mathrm{CG}$, reflected in larger board sizes and independence, are able to resolve the principal-agent conflicts and thus improve disclosure practices, with the ultimate objective of increasing shareholder value.

\subsection{Corporate Disclosure (CD)}

Corporate disclosure continues to be of great interest to analysts, investors and shareholders. It is an integral part of financial reporting and, technically, is the last step in the accountability process in terms of presenting information in the form of financial statements. Al Razeen and Karbhari (2004) defined disclosure as any financial information, quantitative or qualitative, which is intentionally released by the company through official or unofficial channels. Disclosure of information in the annual report may be mandatory or voluntary. Mandatory disclosure is subject to the rules and principles laid down by the regulators; by contrast, VD is subject to the discretion of the company's management (Tsang et al., 2019). Mandatory disclosure refers to the information that a company is required to disclose according to the securities law, accounting principles, and regulatory agencies (Tian \& Chen, 2009).

Stock market regulations worldwide require all listed companies to disclose financial information on an annual basis. Companies must meet minimum disclosure requirements, which vary according to different regulators (Alturki, 2014; Gunawan \& Lina, 2015). Even with governmental regulations, full disclosure is not guaranteed, since corporate reporting regulation aims to provide outside investors with minimal information (Al - Razeen \& Karbhari, 2004). A major issue in the literature, concerning disclosure, is how much information is enough and what the nature of this information is (Gunawan \& Lina, 2015). A general consensus, however, is that disclosure helps investors better understand a company's affairs, thus reducing the knowledge gap between management and investors (Akhtaruddin et al., 2009). Therefore, there are calls and demands for more VD to provide investors with the information they need to satisfy their requirements (Alsaeed, 2006).

\subsubsection{Voluntary Disclosure (VD)}

There have been many attempts to define corporate VD. Although there is, to date, no one definition on which all researchers agree, most agree on the broader concept, which considers any non-mandatory disclosure as VD. Hence, VD discloses additional important information beyond the minimum requirements of applicable capital market regulations required by law and regulatory authorities (Alturki, 2014; Gunawan \& Lina, 2015; Tsang et al., 2019; Ullah et al., 2018). Maskati and Hamdan (2017) defined VD as the action that makes information related to a current situation, action, or decision available, accessible, and understood. The concept of corporate VD has developed over time to include all types of financial and nonfinancial information that are not mandatory and can be provided by a company's management in various forms and through different channels (Bhattacharyya, 2012).

By mastering the regulatory rules of the information 
disclosure market, VD aims to introduce and explain companies' capabilities to investors; drive liquidity in capital markets; ensure more effective capital allocation; reduce capital costs; and achieve more positive communication with investors (Tian \& Chen, 2009). The Financial Accounting Standards Board (FASB) categorises corporate VD into six groups: company background; business data; business data analysis; forward-looking information; management and shareholders information; and unrecognised, intangible assets information. It is important to note that because the disclosure here is voluntary, companies may disclose information in different ways and through different channels, including annual reports, interim reports, analyst presentations, investor relations, press releases, conferences and websites. It is also noteworthy that structured annual reports remain the primary source for independently verifying comprehensive information about managers' performance at regular intervals (Saha \& Kabra, 2020).

Studies have called for more expansive VD to enhance a company's performance (Wadesango et al., 2020), promote confidence in the financial reports (Owais, 2021), and eventually improve shareholders' value. Owais (2021) created a questionnaire to collect data from 374 external and internal Jordanian auditors to determine the role of VD in building confidence in financial reporting. The study results showed that VD promotes confidence in the financial reports of services companies listed in the Jordanian securities commission. Other studies highlight the link between the ownership structures and VD. Desta et al. (2019) investigate the determinants of VD in the annual reports of 107 Tanzanian manufacturing firms for the period 2011-2015. Their results show that concentration of ownership is negatively associated with VD in the sample companies and that foreign ownership is positively associated with VD.

\subsection{Corporate Governance and Voluntary Disclosure}

Research has shown that CG and VD are interrelated. Previous studies have found that CG mechanisms affect VD (e.g. Maskati \& Hamdan, 2017; Al-Shammari \& Al-Sultan, 2010; Akhtaruddin et al., 2009; Cheng \& Courtenay, 2006) and the quality of VD is linked to specific company characteristics (Al-Moataz \& Hussainey, 2013; Maskati \& Hamdan, 2017; Sallehuddin, 2016; Ullah et al., 2018). These studies measured CD by developing an index or score to measure VD in annual reports. It was found that CG characteristics are related to VD levels. Gad (2020) examine selected CG mechanisms in order to determine their impact on the disclosure related to the control system concerned with financial reporting in Germany and Poland. The results indicate that selected CG mechanisms, including the number of board committees and the number of board meetings, have a significant positive influence on the level of disclosure. El-Deeb et al. (2021) examine the extent to which CG affects disclosure tone and their empirical result shows a significant positive impact of CG on disclosure. In Cheng and Courtenay (2006), it was found that companies with boards which held a majority of independent directors had significantly higher levels of VD. Ghazali and Weetman (2006) determined that director ownership was significantly correlated with the extent of VD. Furthermore, the largest shareholders have a powerful interest in firm performance and the capability to increase VD (Li \& Qi, 2008). Sallehuddin (2016) asserted that companies where executive directors held higher proportions of shares contained more VD in their annual reports. Khanifah et al. (2020) examine the effect of CG disclosure on bank performance by building and using an index for 10 Islamic banks operating in Iran, Saudi Arabia and Malaysia. The most frequently reported and disclosed elements are board structure and audit committee. The results provide evidence that Islamic banks with a higher level of CG disclosure reported high operating performance.

Previous studies have adopted many theories to examine the relationship between CG and VD, including agency theory, stakeholder theory and signalling theory (see, e.g. Akhtaruddin et al., 2009; Al-Bassam et al., 2018; Al-Janadi et al., 2013; Al-Moataz \& Hussainey, 2013; Al-Shammari \& Al-Sultan, 2010; Alturki, 2014; Baek et al., 2009; Bouaziz, 2014; Chau \& Gray, 2002; Cheng \& Courtenay, 2006; Clemente \& Labat, 2009; Kumar, 2007; Maskati \& Hamdan, 2017; Matoussi \& Chakroun, 2008; Patelli \& Prencipe, 2007; Sallehuddin, 2016; Ullah et al., 2018). The present study adopts agency theory as an analytical lens, because agency theory is more closely related to CG than other theories. Many other studies have also used agency theory (see e.g. Al-Bassam et al., 2018; Buallay et al., 2017; Al-Shammari \& Al-Sultan, 2010; Akhtaruddin et al., 2009; Patelli \& Prencipe, 2007; Ghazali \& Weetman, 2006).

Agency theory posits that firms may voluntarily disclose more information to mitigate the information asymmetry that arises from conflicts between shareholders and managers (Lambert, 2001; Zayoud et al., 2011). Accounting researchers have also examined the possible determinants of disclosure using agency theory to explain the existing variation in VD practices (Elfeky \& Nasiri, 2017).

\subsection{CG and VD in Saudi Arabia}

In 1965, the Ministry of Commerce issued the Companies Law, which stipulated CG provisions in order to protect shareholders' interests and regulated the CG practices of listed companies in Saudi Arabia (Haniffa \& Hudaib, 2007). The law emphasises shareholders' rights by setting conditions for several aspects of business, such 
as legal frameworks through which companies can be established, operated and monitored. Likewise, it provides general guidelines concerning registration requirements; minimum capital to be maintained; number of partners and directors and ways of nominating them; monitoring of company accounts; annual audit of the accounts and so on. It consists of 12 parts and regulates all companies in Saudi Arabia. Part five relates to joint-stock companies and includes 98 articles that mostly cover the composition of boards of directors and their levels of independence. During the mid-1960s, the requirements for disclosure in Saudi Arabia were few and the Companies Law was the major source of CG.

In 1985, the Ministry of Commerce aggressively pursued CG reforms to significantly improve the framework and mechanisms for Saudi companies' CG practices by issuing the disclosure and transparency standard. Later, in 2003, the Capital Market Law was released, and the Capital Market Authority (CMA), i.e. a government agency empowered with complete legal, financial and administrative independence, was also instituted. The Capital Market Law brought the entire Saudi capital market under the umbrella of the CMA, a single regulator. The institution of the CMA marked a big step forward for Saudi Arabia, as more significant externally-focused corporate reform initiatives in the country's history were witnessed from that point onwards (Hussainey \& Al-Nodel, 2008). One of the country's most recognised CG initiatives was the development and promulgation of the Corporate Governance Law (Al-Janadi et al., 2013). In 2006, the CMA released the first set of Corporate Governance Regulations (CGR), which mostly originated in the Companies Law of 1965. Since that time, there have been many updates to the CGR, to keep abreast of reforms and changes in the broader economy.

In 2007, the formation of the Saudi Stock Exchange (Tadawul) was approved by the Council of Ministers as a joint stock company and the official source for all market information. To date, Tadawul is the only entity in Saudi Arabia licensed to act as the securities exchange regulator (the Exchange) for listing and trading securities and depositing, transferring, clearing, settling and registering ownership of securities. The responsibilities of the stock exchange and the depository center are clearly defined in the Capital Market Law.

In 2017, the CMA approved the amended CG regulation in light of the amendments made to the Companies Law. The main objectives of Saudi's CGR were to provide a universal guide to the regulations, rules, and practices for listed firms and investors (Buallay et al., 2017). The CGR provide the standards and detailed rules that regulate the management of listed firms, in order to ensure compliance with best practices of CG and thereby protect the rights and interests of stakeholders and shareholders. The CGR are composed of eight main parts: rights of shareholders, board of directors, company committees, internal control, external auditors, shareholders, professional and ethical standards, and disclosure and transparency (CMA, 2017).

CGR recommend an ideal board size of 3-11 persons, and a non-executive majority among board members. The minimum number of non-executive members should be at least two, or one-third of the board, whichever is greater. Additionally, the role of the board chair must not be held by an individual who is also the CEO or who occupies another executive position. Directors may sit on the boards of multiple companies, up to a maximum of five at a time (CMA, 2017). All board members are expected to have adequate access to information about the firm in order to enable the board to effectively discharge its duties (Robertson et al., 2013). Furthermore, the CMA recommends that audit committees be composed of three to five members; they can be shareholders or others. At least one member should be an independent director, and no executive director is to be on the committee. Finally, without specifying any minimum number, the CGR encourage board chairs to hold regular meetings. As is the case in many other countries, current regulations on financial reporting in Saudi Arabia oblige companies to adhere to a minimum disclosure requirement, and companies can choose to disclose any additional information beyond this requirement. Various forces influence companies in carrying out $\mathrm{CD}$, the main one being the effort to reduce information asymmetry among market participants and conflicts of interest in listed companies (Alturki, 2014; Chau \& Gray, 2002; Meek et al., 1995).

\subsection{Hypotheses Development}

VD in annual reports is currently a rapidly-growing area of research in the field of accounting (Alturki, 2014). Several studies examine how variables such as CG mechanisms, ownership structure and firm-specific characteristics affect VD (Ullah et al., 2018; Maskati \&Hamdan, 2017; Sallehuddin, 2016; Alturki, 2014; Al-Moataz \& Hussainey, 2013; Al-Janadi et al., 2013; Al-Shammari \& Al-Sultan, 2010; Clemente \& Labat, 2009; Akhtaruddin et al., 2009; Cheng \& Courtenay, 2006; Eng \& Mak, 2003). Studies on VD are not new in Saudi Arabia. Mariq (2009) examined VD in the annual reports of 52 Saudi listed companies in 2005. To conduct the study, the author constructed a disclosure index consisting of 60 items that represent the basic items of VD. The results indicated a wide variation in the nature and extent of VD among the companies studied. The study also found that companies tended to voluntarily disclose more than the required information. The following subsections further shed light on these studies.

\subsubsection{Non-executive Directors and VD}

Board structure plays an essential role in mitigating 
agency problems (Ullah et al., 2018), although previous studies report mixed results. Ke et al. (2020) provide empirical evidence that board directors help improve VD quality by supplying useful information to management and serving as effective advisors. Al-Shammari and Al-Sultan (2010) surveyed a sample of 170 firms listed on Kuwait to investigate potential relationships between CG characteristics and VD in their annual reports. They found that the proportion of non-executive directors on boards, per the CGR, was not significant and did not influence VD. Al-Moataz and Hussainey (2013) examined the relationship between some CG mechanisms and characteristics of firms, as well as the disclosure level of CG information, in 97 Saudi listed companies for the period 2006-2007. Their results indicated a negative correlation between the independence of the board of directors and the levels of VD in CG; a positive correlation between the size of the audit committee and the level of VD in CG; and no correlation between the level of VD and firm size in CG. They also found that a higher number of non-executive directors on the board resulted in practices with a low level of CG disclosure in Saudi Arabia. Firms' characteristics, such as leverage, liquidity, and profitability were related to the level of disclosure in CG.

Similarly, Ullah et al. (2018), using 62 manufacturing companies listed in Pakistan from 2013 to 2015, examined the impact of CG on VD and also found that the proportion of non-executive directors did not significantly influence VD. On the other hand, Al-Janadi et al. (2013) examined both external and internal CG mechanisms and how they impacted VD in 87 Saudi listed companies for 2006 and 2007. Their results showed a significant positive relationship between the board size, audit quality, and the proportion of non-executive directors on the board and VD. In keeping with the majority of empirical findings, which indicate a negative association between the composition of the board and VD, the authors present the first hypothesizes:

H1: There is a negative relationship between the number of non-executive board directors and the level of voluntary disclosure in the annual reports of Saudi companies.

\subsubsection{Board Size and VD}

Boards differ in size from one company to another. Boards can vary in sizes (meaning, the number of members) and these variations may impact the effectiveness of how the board monitors and guides a given company. Although several studies have discussed the effect of board size on VD, the results have been inconclusive. Akhtaruddin et al. (2009) used an empirical method to analyze the extent of CG and VD in a sample of 105 firms listed in Malaysia at the end of 2002. They included the following governance factors: board size; the number of non-executive and independent directors on the board; family control; outside share ownership; and the percentage of audit committee members to total board size. The findings suggested that a larger board would voluntarily provide more information than a smaller one. Clemente and Labat (2009) used a cross-sectional analysis to study the impact of CG mechanisms on VD in 62 Spanish listed firms in 2005. Their analysis established a positive relationship between $t$ board size and the extent of VD. In Bahrain, Maskati and Hamdan (2017) also employed cross-sectional analysis to 41 listed firms for the year 2013, and concluded that when the side of the board of directors was between 7-13 members, CG had a positive relationship with VD. Sallehuddin (2016) found a significant relationship with the board's size when examining the relationships of CG characteristics and ownership to the level of VD, using the annual reports of 254 Malaysian listed firms in year 2010. Similarly, Al-Janadi et al. (2013) found that board size in Saudi listed companies had a significant positive association with VD. Finally, Al-Nimer (2019) also shows a significant positive relationship between the number of board members and the level of VD among listed Jordanian firms.

Conversely, Matoussi and Chakroun (2008) studied the interactions between the composition of the board, ownership concentration, and VD for nonfinancial Tunisian listed firms for the years 2003-2005 and reported no relationship between the size of the board and the extent of VD in the annual reports. Similarly, Cheng and Courtenay (2006) examined 104 firms listed on the Singapore Exchange in 2000. Their analysis of board monitoring and the level of VD showed no effect of board size on disclosure. Other researchers have even gone so far as to argue that increasing board size would reduce VD (Ullah et al., 2018). Abdelqader et al. (2021) explore the impact of CG mechanisms on the compliance of 314 non-listed companies with International Financial Reporting Standards (IFRS) disclosure requirements. The result of this sample, which included companies from across the gulf region, indicate that board size has no clear impact on disclosure. Similarly, Masum et al. (2020) study the main determinants that influence corporate CG in Bangladesh and find no significant positive association between VD and board size. Ahmed (2021) reaches a similar result. Despite these counter examples, the majority of empirical findings indicate a positive association between board size and VD, so this study hypothesises the following:

H2: There is a positive relationship between the board size and the level of voluntary disclosure in the annual reports of Saudi companies.

\subsubsection{Independent Directors and VD}

A larger ratio of independent directors to the board's total size helps to assure board's independence, meaning that monitoring practices will have greater effectiveness, 
assuming board members are not unduly biased. Hence, having more independent directors may prompt management to voluntarily disclose more information (Abdel-Fattah, 2008; Akhtaruddin et al., 2009; Cheng \& Courtenay, 2006). Clemente and Labat (2009) found a positive relationship between the proportion of independent directors and the extent of VD. Mansulu (2021) confirms this by using regression analysis to measure VD and to examine whether there was a relationship between CG determinants and the level of VD. The result shows a positive association between the level of VD and the number of independent directors. Patelli and Prencipe (2007) also investigated the correlation between VD and independent directors in 175 Italian listed nonfinancial companies for 2002, finding a positive association between the number of independent directors on the board and the level of VD in their annual reports. Several other studies (Maskati \& Hamdan, 2017; Matoussi \& Chakroun, 2008) have shown a positive relationship between the independence of the board of directors principal and VD, and proven that the extent of VD is improved with greater independence on behalf of the board of directors. Some studies, however, have reached different conclusions. For example, Sallehuddin (2016) found that the board's independence did not significantly influence VD. In keeping with the majority of empirical findings, which indicate a positive association between the board's independence and VD, this study hypothesises the following:

H3: There is a positive relationship between board independence and the level of voluntary disclosure in the annual reports of Saudi companies.

\subsubsection{Audit Committee Size and VD}

Empirical evidence from previous studies has shown mixed results concerning the effect of audit committees on VD. In a study of listed companies in Kuwait in 2007, Al-Shammari and Al-Sultan (2010) indicated that a voluntary audit committee was likely to demand more VD. They showed that even though the Kuwaiti company law during that time did not oblige companies to establish audit committees, a number of listed companies created and formed them to encourage VD. Further, some empirical studies found that having a greater number of members on an audit committee had a significant positive influence on VD, i.e. the greater the number of members on the audit committee, the higher the level of disclosure (Al-Moataz \& Hussainey, 2013; Ullah et al., 2018). On the contrary, Akhtaruddin et al. (2009) and Sallehuddin (2016) indicated that audit committee size had no significant impact on the level of VD. Abdelqader et al. (2021) examine the impact of CG mechanisms on the disclosure of 314 non-listed companies across the Gulf region, concluding that the audit committee makeup has no effect. Al-Nimer (2019) has gone further and reported a negative association between the size of the audit committee and level of VD among listed Jordanian firms. Following the majority of empirical findings, which indicate a positive association between audit committee size and VD, this study hypothesises the following:

H4: There is a positive relationship between the size of the audit committee and the level of voluntary disclosure in the annual reports of Saudi companies.

In summary, previous research has examined the relationships between CG mechanisms and VD which may enhance transparency in annual reports. Some of these studies have analyzed the relationships among the level of VD and other variables, including CG mechanisms, ownership structure and firm-specific characteristics. However, most of these studies were conducted in developed countries in the global west and east, and only a few studies attended to developing countries, including in Saudi Arabia. Further, previous research concerning Saudi Arabia neglects some CG mechanisms, such as board size and number of independent, non-executive board members. The present study narrows this gap by examining the relationship between CG mechanisms and VD. It focuses on board size, non-executive directors, board independence and audit committees. Furthermore, the present study covers a longer period than those used in previous Saudi studies (see, e.g. Al-Janadi et al., 2013; Al-Moataz \& Hussainey, 2013).

\section{Methodology}

This study employs a correlational research design that attempts to explore the relationship between VD and CG in the annual reports of Saudi listed companies. Table 1 summarises the description and measurement of the dependent variable, independent variables and other control variables.

\subsection{Dependent Variable}

The dependent variable for this study is defined as voluntary disclosure. The unweighted approach is used to create a VD index scoring the VD of companies. This approach has been used by several studies (see, e.g. Akhtaruddin et al., 2009; Alsaeed, 2006; Ghazali \& Weetman, 2006; Kristandl \& Bontis, 2007; Patelli \& Prencipe, 2007). This study developed an index after checking its items against the mandatory disclosure requirements of the Saudi regulations, in order to account for the levels of VD by Saudi firms in their annual reports. The index used in this study is composed of 30 items. Each company was investigated, and each index item received a score of 1 if the company met the disclosure requirements and a score of 0 if it did not. The VD index includes the level of strategic, nonfinancial and financial information that is voluntarily disclosed. 


\subsection{Independent Variables}

$\mathrm{CG}$ was chosen as the main independent variable - in particular, board size, board independence, audit committee and non-executive directors. These independent variables were chosen following previous studies (Ke et al., 2020; Al-Shammari \& Al-Sultan, 2010; Albassam, 2014; Patelli \& Prencipe, 2007; Ghazali \& Weetman, 2006). The measurement of these variables is presented in Table 1.

\subsection{Control Variables}

Previous studies have found that other firm characteristics may affect VD. Therefore, certain control variables were used in this study to control the relationship between the dependent and independent variables, including firm size (Al-Bassam et al., 2018; Laksmana, 2008), firm profitability (Albassam \& Ntim, 2017; Cho et al., 2020; Clemente \& Labat, 2009; Collett \& Hrasky, 2005; Eng \& Mak, 2003), leverage (Al-Bassam et al., 2018; Eng \& Mak, 2003; Tsang et al., 2019; Ullah et al., 2018), firm age (Lee \& Lee, 2014; Maskati \& Hamdan, 2017) and audit firm size (Alturki, 2014; Buallay et al., 2017; Maskati \& Hamdan, 2017; Tsang et al., 2019).

To test the present study's hypotheses, the following model was used:

Model:

$$
\begin{gathered}
V D_{i t}=\alpha_{0}+\beta_{1} B S_{i t}+\beta_{2} I N D_{i t}+\beta_{3} A C_{i t}+\beta_{4} N E X_{i t} \\
+\sum_{i=1}^{n} \beta_{i} \text { CONTROLS }_{i t}+\varepsilon_{i t}
\end{gathered}
$$

\subsection{Data Collection}

Secondary data for CG was mainly collected manually, directly from annual reports. Reports were accessed through the Tadawul website or through the companies' websites. VD data were collected via a content analysis of annual reports, as in previous studies (Al-Shammari \& Al-Sultan, 2010; Ghazali \& Weetman, 2006; Habbash et al., 2016). The data collected from the companies' annual reports and financial statements were classified and arranged in an Excel file. The VD data were manually extracted from the contents of each annual report and compared to the 30-item VD checklist. Then, a score of 1 was attributed if the information was disclosed and score of 0 if not.

\subsection{Sample}

The sample for this study covers the materials sector from nonfinancial listed companies as classified by Tadawul. This sector consists of an industry group including chemicals, building materials, metals and mining, containers and packing, and paper and forest production, which represent $26.92 \%$ of the nonfinancial segment of the market, with 42 listed companies. Twenty companies were excluded due to the lack of annual reports for 2015 and 2016. After the exclusion, the sample consisted of 22 companies with 110 observations ( $\mathrm{n}=$ 110). The study covered the 2015-2019 period. Table 2 presents the sample composition.

\begin{tabular}{|c|c|c|}
\hline Variable & Definition & Measurement \\
\hline$\frac{\text { Dependent Variable }}{\text { VD }}$ & $\begin{array}{l}\text { Voluntary disclosure } \\
\text { score }\end{array}$ & $\begin{array}{l}\text { The total number of points awarded for voluntary disclosure; each item scored } 1 \text { if } \\
\text { disclosed and } 0 \text { if not. The complete voluntary disclosure index was then computed } \\
\text { for each sample firm as a ratio of the entire disclosure score to the maximum } \\
\text { possible disclosure by the firm. }\end{array}$ \\
\hline$\frac{\text { Independent Variables }}{\mathrm{BS}}$ & Board size & Total number of directors on the board of directors \\
\hline IND & Independent directors & The proportion of non-executive directors to the total number of directors $\%$ \\
\hline $\mathrm{AC}$ & Audit committee Size & Number of members serving on the audit committee \\
\hline NEX & $\begin{array}{c}\text { Non-executive } \\
\text { directors }\end{array}$ & The ratio $\%$ of non-executive directors to the total board size \\
\hline$\frac{\text { Controls Variables }}{\text { FS }}$ & Firm size & Natural logarithm of total assets \\
\hline $\mathrm{ROA}$ & Profitability & Return on assets $\%$ \\
\hline LV & Leverage & Debt ratio \% (total debt divided by total assets) \\
\hline $\mathrm{FE}$ & Firm age & The number of years since the company was established \\
\hline AS & Audit firm size & The company's auditing firm size ( 1 if Big 4 audit firms, 0 if not) \\
\hline
\end{tabular}

Table 1. Definition and measurement of variables 
Table 2. Sample composition

\begin{tabular}{|c|c|c|c|c|c|}
\hline Details & 2015 & 2016 & 2017 & 2018 & 2019 \\
\hline Chemicals & 12 & 12 & 12 & 12 & 12 \\
\hline Building materials & 20 & 21 & 22 & 22 & 22 \\
\hline Metals and mining & 2 & 2 & 2 & 2 & 2 \\
\hline Containers and packing & 3 & 3 & 4 & 4 & 4 \\
\hline Paper and forest production & 2 & 2 & 2 & 2 & 2 \\
\hline Initial sample & 39 & 40 & 42 & 42 & 42 \\
\hline Missing data & 20 & 20 & 20 & 20 & 20 \\
\hline Final sample & 19 & 20 & 22 & 22 & 22 \\
\hline
\end{tabular}

\subsection{Statistical Tools for Data Analysis}

Data were analysed using the Stata software for statistical analysis. The analysis of the results is based on the outcome of the statistical tool. A comparison was made with previous studies both in Saudi Arabia and other countries. The study used Pearson's correlation coefficients to examine the correlation between study variables similar to other studies (Cho et al., 2020; Eng \& Mak, 2003; Ghazali \& Weetman, 2006; Laksmana, 2008). It also used ordinary least squares (OLS) regression to examine the relationship between VD and the explanatory variables similar to other studies (Alsaeed, 2006; Alturki, 2014; Eng \& Mak, 2003; Laksmana, 2008).

\section{Data Analysis and Results}

\subsection{Descriptive Analysis}

This study examines the relationship between VD and CG mechanisms. Table 3 shows the descriptive statistics for all the main variables. The VD ranges between 13\% and $50 \%$, and the mean is $29 \%$ lower than average and consistent with Alsaeed (2006). This result shows that, on average, the sample discloses only $29 \%$ of the checklist items. This average rate is considered very low compared to the maximum rate of VD by the firms, which is $50 \%$.

The BS shows that the maximum number is equal to 11 and the minimum is equal to five. This result meets the CG regulation postulating that the board size should be more than three and less than 11 members (CMA, 2017). It also indicates that some firms have five members on their boards, while others have 11. Further, the results show that the average percentage of independent directors (IND) out of the total board size is $90 \%$. This means that about $90 \%$ of the sample firms' directors are independent. Therefore, the sample indicates that Saudi listed companies tend mostly to appoint outside directors as their board members. This percentage is consistent with the Saudi CGR requirement stating that the board of directors must have at least two independent members or a number representing one-third of its total members (whichever is greater). The average percentage of non-executive directors (NEX) out of the total number of directors on the board is $38.6 \%$. Such results agree with the CMA (2017) in that when forming the board, non-executive directors should be the majority of the board. This means that $38.6 \%$ of the directors for the sample firms are non-executive directors.

The results show that the audit committee size (AC) is between three and seven members, which meets the CGR requirement that the number of audit committee members shall not be less than three or greater than five. The maximum number did not meet the criteria for a year in one company due to the replacement of members during that year.

Table 3. Descriptive statistics

\begin{tabular}{|c|c|c|c|c|c|}
\hline VARIABLES & $\mathrm{N}$ & MEAN & SD & MIN & MAX \\
\hline VD & 110 & 0.29 & 0.08 & 0.13 & 0.50 \\
\hline BS & 110 & 8.57 & 1.44 & 5.00 & 11.00 \\
\hline IND & 110 & 0.90 & 0.09 & 0.67 & 1.00 \\
\hline NEX & 110 & 0.39 & 0.17 & 0.00 & 0.86 \\
\hline AC & 110 & 3.56 & 0.84 & 3.00 & 7.00 \\
\hline
\end{tabular}

\subsection{Pearson's Correlation Coefficients}

Before discussing the regression analysis results, it is important first to review the results in terms of possible multicollinearity. The Pearson's correlation coefficient is viewed as an effective and powerful analytic tool for detecting any multicollinearity among the variables. According to Bryman and Cramer (2002) 'the Pearson's between each pair of independent variables should not exceed 0.80; otherwise the independent variables that show a relationship at or in excess of 0.80 may be suspected of exhibiting multicollinearity' (p. 244). This can affect the results of multiple regressions. In this study, no high correlation among the independent variables was found, as shown in Table 4.

Table 4 presents the Pearson's correlation coefficient between VD and independent variables. It reveals that some variables have significant correlations with the disclosure index. The analysis shows that there is a significantly positive correlation relationship between VD, BS (0.365), IND (0.192), AC (0.207), and NEX (0.479). 
Additionally, the results show that control variables have a positive correlation with the dependent variable. However, their correlations are not significant.

Notably, there is a significant positive correlation between the BS and IND. It is noteworthy that there is a significant negative correlation between FE (0.377) and $\mathrm{LV}$, and a relatively less negative correlation between AS (0.039) and LV. By contrast, other independent variables show some positive correlations: AC and IND (0.301), and NEX and IND (0.330).

\subsection{Regression Analysis and Hypothesis Testing}

Multiple regression analysis was used to examine the relationship between VD and CG in nonfinancial Saudi firms' annual reports between 2015 and 2019. Table 5 shows the model's regression parameters. The F-value of Saudi companies between 2015 and 2019 is 7.08 (significant at 0.1), which means that the model as a whole is significant and all the independent variables significantly affect the dependent variable. The probability is equal to 0.00 , which is less than 0.05 ; this means that the independent variables reliably predict the dependent variable. This lower value indicates that at least some of the regression coefficients are nonzero and that the regression equation has some validity in the fit of the data. The model's $\mathrm{R}^{\wedge} 2$ is $(0.389)$, which denotes that it can explain approximately $38.9 \%$ of the variability in the data. This means that other variables that were not included in the model account for approximately $61.1 \%$ of the variability in the VD. The adjusted $\mathrm{R}^{\wedge} 2$ indicates that about $33.4 \%$ of the VD variance is explained by the independent variables. The explanatory power of this model (adjusted $\mathrm{R}^{\wedge} 2$ ) is higher than what other studies have found, for example Eng and Mak (2003): 20.61\% and Clemente and Labat (2009): 24.65\%. However, the adjusted $\mathrm{R}^{\wedge} 2$ is lower than that of Chau and Gray (2002): 42.7\%; Ghazali and Weetman (2006): 36.1\%; Habbash et al. (2016): 44.5\%; and Ullah et al. (2018): $50.4 \%$.

Table 4. Pearson's correlation coefficient

\begin{tabular}{|c|c|c|c|c|c|c|c|c|c|c|}
\hline Item & VD & BS & IND & $\mathrm{AC}$ & NEX & FS & ROA & LV & $\mathrm{FE}$ & AS \\
\hline VD & 1.0000 & & & & & & & & & \\
\hline BS & $\begin{array}{c}0.3646 \\
0.0001 *\end{array}$ & 1.0000 & & & & & & & & \\
\hline IND & $\begin{array}{c}0.1916 \\
0.0450 * *\end{array}$ & $\begin{array}{l}0.0087 \\
0.9279\end{array}$ & 1.0000 & & & & & & & \\
\hline $\mathrm{AC}$ & $\begin{array}{c}0.2069 \\
0.0301 * *\end{array}$ & $\begin{array}{c}0.2760 \\
0.0035^{*}\end{array}$ & $\begin{array}{c}0.3009 \\
0.0014 *\end{array}$ & 1.0000 & & & & & & \\
\hline NEX & $\begin{array}{c}0.4788 \\
0.0000^{*}\end{array}$ & $\begin{array}{l}0.0256 \\
0.7903\end{array}$ & $\begin{array}{c}0.3303 \\
0.0004^{*}\end{array}$ & $\begin{array}{l}0.0940 \\
0.3289\end{array}$ & 1.0000 & & & & & \\
\hline FS & $\begin{array}{c}0.2523 \\
0.0078^{*}\end{array}$ & $\begin{array}{c}0.2996 \\
0.0015^{*}\end{array}$ & $\begin{array}{c}0.1885 \\
0.0486^{* *}\end{array}$ & $\begin{array}{c}0.2976 \\
0.0016^{*}\end{array}$ & $\begin{array}{c}0.2941 \\
0.0018^{*}\end{array}$ & 1.0000 & & & & \\
\hline ROA & $\begin{array}{l}0.1262 \\
0.1891\end{array}$ & $\begin{array}{c}0.2757 \\
0.0036^{*}\end{array}$ & $\begin{array}{l}0.0160 \\
0.8679\end{array}$ & $\begin{array}{l}0.0663 \\
0.4914\end{array}$ & $\begin{array}{l}0.0505 \\
0.6006\end{array}$ & $\begin{array}{l}0.0206 \\
0.8307\end{array}$ & 1.0000 & & & \\
\hline LV & $\begin{array}{l}0.0168 \\
0.8616\end{array}$ & $\begin{array}{l}0.0530 \\
0.5823\end{array}$ & $\begin{array}{l}0.0213 \\
0.8255\end{array}$ & $\begin{array}{l}0.1337 \\
0.1637\end{array}$ & $\begin{array}{l}0.1538 \\
0.1087\end{array}$ & $\begin{array}{l}0.0001 \\
0.9993\end{array}$ & $\begin{array}{c}0.5739 \\
0.0000^{*}\end{array}$ & 1.0000 & & \\
\hline $\mathrm{FE}$ & $\begin{array}{c}0.2717 \\
0.0041^{*}\end{array}$ & $\begin{array}{c}0.3288 \\
0.0005^{*}\end{array}$ & $\begin{array}{l}0.0822 \\
0.3931\end{array}$ & $\begin{array}{l}0.0740 \\
0.4421\end{array}$ & $\begin{array}{c}0.2248 \\
0.0182 * *\end{array}$ & $\begin{array}{l}0.0969 \\
0.3138\end{array}$ & $\begin{array}{c}0.2989 \\
0.0015^{*}\end{array}$ & $\begin{array}{l}-0.3766 \\
0.0001 *\end{array}$ & 1.0000 & \\
\hline AS & $\begin{array}{c}0.2931 \\
0.0019^{*}\end{array}$ & $\begin{array}{c}0.2946 \\
0.0018^{*}\end{array}$ & $\begin{array}{c}0.2178 \\
0.0223 * *\end{array}$ & $\begin{array}{l}0.0162 \\
0.8663\end{array}$ & $\begin{array}{c}0.2073 \\
0.0298^{* *}\end{array}$ & $\begin{array}{c}0.3211 \\
0.0006^{*}\end{array}$ & $\begin{array}{c}0.3853 \\
0.0000^{*}\end{array}$ & $\begin{array}{l}-0.0385 \\
0.6894\end{array}$ & $\begin{array}{l}0.1203 \\
0.2106\end{array}$ & 1.0000 \\
\hline & & & Significant & $0.01 * * S$ & ificant at 0 & $* * *$ Sign & ant at 0.10 & & & \\
\hline
\end{tabular}

Table 5. Regression results

\begin{tabular}{|c|c|c|c|c|}
\hline $\mathrm{N}=110$ & $\mathrm{~F}(9,100)=7.08$ & $\mathrm{~F}$ significance $=0.000$ & $\mathrm{R}^{2}=0.389$ & Adj $R^{2}=0.334$ \\
\hline VD & \multicolumn{2}{|r|}{ Coef. } & $\mathrm{t}$ - values & $P>|t|$ \\
\hline $\mathrm{BS}$ & \multicolumn{2}{|r|}{0.014} & 2.710 & 0.008 \\
\hline IND & \multicolumn{2}{|r|}{0.049} & 0.550 & 0.581 \\
\hline $\mathrm{AC}$ & \multicolumn{2}{|r|}{0.012} & 1.400 & 0.164 \\
\hline NEX & \multicolumn{2}{|r|}{0.192} & 4.490 & 0.000 \\
\hline FS & \multicolumn{2}{|r|}{-0.000} & -0.210 & 0.833 \\
\hline ROA & \multicolumn{2}{|r|}{0.030} & 0.320 & 0.753 \\
\hline LV & \multicolumn{2}{|r|}{0.054} & 1.350 & 0.179 \\
\hline FE & \multicolumn{2}{|r|}{0.001} & 1.220 & 0.225 \\
\hline AS & \multicolumn{2}{|r|}{0.016} & 1.030 & 0.307 \\
\hline _cons & \multicolumn{2}{|r|}{-0.031} & -0.300 & 0.762 \\
\hline \multicolumn{5}{|c|}{ Significant at $0.05 \%$} \\
\hline
\end{tabular}




\subsubsection{Non-executive Directors}

Table 5 shows a positive relationship between NEX and the level of VD (coef. = 0.192), with (0.00) p-value; there is a statistically significant relationship between the NEX and the level of VD. The coefficient of NEX means that a one percent change in NEX brings a $19.2 \%$ change in the VD average. The result suggests that a greater number of non-executive directors on the board leads to more VD. If listed companies desire to increase VD and transparency, they must increase the number of NEX members of their boards. CG regulators striving to increase transparency and VD must design their regulations to oblige companies to increase the number of NEX members of their boards. This result is consistent with Al-Janadi et al.'s (2013) study and inconsistent with other studies (Al-Moataz \& Hussainey, 2013; Al-Shammari \& Al-Sultan, 2010; Ullah et al., 2018). Based on this result, the first hypothesis is rejected:

H1: There is a negative relationship between the number of non-executive board directors and the level of voluntary disclosure in the annual reports of Saudi companies.

\subsubsection{Board Size}

Table 5 also shows a positive relationship between BS and the level of VD (coef. $=0.014$ ), with (0.008) p-value; there is a statistically significant relationship between the BS and the level of VD. The coefficient of BS means that one percent change in BS brings a 1.4\% change in the VD average. The result suggests that increasing the board size leads to more VD. Hence, if Saudi listed companies wish to increase their VD and transparency, the number of their board members should be increased to the highest number specified by the CMA, i.e. not exceeding 11 members. This result is consistent with much of the literature (Akhtaruddin et al., 2009; Al-Janadi et al., 2013; Clemente \& Labat, 2009; Maskati \& Hamdan, 2017). However, it is inconsistent with other studies, which found that increases in board sizes reduce VD (Cheng \& Courtenay, 2006; Matoussi \& Chakroun, 2008; Sallehuddin, 2016; Ullah et al., 2018). This result supports the second hypothesis, so the latter is accepted:

H2: There is a positive relationship between the board size and the level of voluntary disclosure in the annual reports of Saudi companies.

\subsubsection{Independent Directors}

Table 5 shows a positive relationship between IND and the level of VD (coef. $=0.049$ ), with $(0.581)$ p-value. Statistically, the relationship between the IND and the VD is insignificant. This result is consistent with (Sallehuddin, 2016) and with many results in the literature, which demonstrated that when independent directors are the majority on the board of directors, the company will tend to release more information (e.g. Akhtaruddin et al., 2009; Cheng \& Courtenay, 2006; Clemente \& Labat, 2009;
Laksmana, 2008; Maskati \& Hamdan, 2017; Matoussi \& Chakroun, 2008; Patelli \& Prencipe, 2007). Based on this result, the third hypothesis is accepted:

H3: There is a positive relationship between board independence and the level of voluntary disclosure in the annual reports of Saudi companies.

\subsubsection{Audit Committee}

Table 5 shows a positive relationship between $\mathrm{AC}$ and the level of VD (coef. $=0.012$ ), with $(0.164)$ p-value; however, the association is statistically insignificant. The relationship's insignificance is consistent with Akhtaruddin et al. (2009) and Sallehuddin (2016). The positive relationship is consistent with Al-Moataz and Hussainey (2013), Al-Shammari and Al-Sultan (2010) and Ullah et al. (2018), in that a large number of members on the audit committee leads to greater disclosure. Based on this result, the fourth hypothesis is accepted:

H4: There is a positive relationship between the size of the audit committee and the level of voluntary disclosure in the annual reports of Saudi companies.

\subsection{Robustness Test:}

To test the homoscedasticity of the linear regression model, Breusch-Pagan test was used and the result is shown in Table 6.

Table 6. Robustness result

\begin{tabular}{|c|}
\hline Ho: Constant variance \\
\hline Variables: fitted values of VD \\
\hline chi2(1) $=1.22$ \\
\hline Prob $>$ chi2 $=0.2689$ \\
\hline
\end{tabular}

Constant variance is rejected because the Prob chi2 is greater than 0.05 , which indicate that the data are free from homoscedasticity.

\subsection{Discussion}

From the analysis, it can be concluded that if listed companies wish to increase $\mathrm{VD}$, the number of non-executive members on the board must be increased. CG regulators should oblige listed companies to increase the number of non-executives in order to increase transparency and VD. The result supports the CMA's composition of board number, whereby the majority of boards should be non-executive (CMA, 2017). Further, CG regulators should increase the minimum number of non-executives on the boards to gain the desired increase in the level of VD. Also, Saudi listed companies are advised to increase their numbers of board members to the maximum number specified by the CMA, i.e. 11 members. 
Further, the findings show that the CG mechanisms used in this study (size of the board of directors, number of non-executive directors, independent directors, and audit committees) influence VD. This may be due to the fact that more members means more opinions and points of view. The increase in non-executive members may be a reason for increased VD, in terms of the companies' desire to form positive relationships with stakeholders by sharing and disclosing more information to them. However, the findings show no statistically significant association between IND, AC and the level of VD in Saudi listed companies. AC is insignificantly related to VD due to the focus on internal processes rather than external stakeholders. IND is also insignificant in relation to VD due to the lack of qualifications and expertise of these members resulting from weak selection mechanisms.

Agency theory is key to interpreting these results. The findings support the theory's presumption that external and internal processes of control and monitoring (characteristics of the boards) complement the mitigation of agency conflicts and information asymmetry. Both the boards and the audit committees are positively associated with VD. For the reduction of information unevenness, it can be observed that disclosure is a useful monitoring tools for aligning the different interests of managers and shareholders (Craswell \& Taylor, 1992). However, for disclosure to achieve its objectives, the supervisory role of the board of directors is vital to ensure that disclosed information provides a sufficiently comprehensive view of the company (Donnelly \& Mulcahy, 2008). In order to be effective as monitors, the board must have certain characteristics in terms of boards' size and composition. The results show that larger, more active boards with a majority of non-executive directors tend to favour greater VD. The results also show that the size of the board can contribute to the successful monitoring of a company, favouring $\mathrm{VD}$, and as a result reducing potential agency costs. Larger boards also have a greater ease in performing their monitoring functions, as these involve the presence of many members and a diversity of skills and experiences. Thus, larger boards may better mitigate agency conflicts among shareholders (Di Pietra et al., 2008; Larmou \& Vafeas, 2010).

Further, the results highlight how board independence and non-executive directors may positively influence VD. The presence of non-executive and independent members is an effective tool for supervising information collection, processes of representation, and the actions of management (Rosenstein \& Wyatt, 1990). The increase of independent board members leads to voluntarily providing more information, which in turn reduces opportunistic behaviours. This suggests that higher numbers of independent members, and subsequent increases in monitoring may prompt managers to increase VD. Further, a greater percentage of independent members may help to ensure the effectiveness of the audit committee, again producing more VD. In fact, effective supervision by the audit committee can improve both the veracity of the disclosure and the information asymmetry between shareholders and managers. Overall, these results support arguments in favour of a complementary relationship between governance and disclosure.

\section{Conclusions}

This study examined the relationships between CG and VD. It determined how board size, independent directors, audit committees and non-executive directors enhance governance practices, thereby increasing VD in Saudi Arabia. This study investigated VD in Saudi Arabia from 2015 to 2019 by analysing the panel data of 110 nonfinancial firm-year observations, using both content analysis and OLS regression analysis. The study used a VD index comprised of 30 items. The results provide evidence of a significant positive relationship between NEX, BS and the level of VD, as well as a positive relationship between IND, AC and the level of VD. This indicates that these variables in $\mathrm{CG}$ are the main mechanisms driving VD in Saudi Arabia. The study shows that the independence of the board directors positively and significantly affects the extent of VD, which means that Saudi firms with a high number of independent non-executive directors are expected to voluntarily disclose more information. Furthermore, increasing board size will convince shareholders that the company has better governance.

The findings reported in this study have notable implications for regulators, policy-makers, listed companies and researchers who want to elevate corporate VD by improving CG mechanisms. This study helps regulators of CG and company directors understand the factors that have an effect on VD. The findings in this study could support calls to extend disclosure requirements in agency settings with a large presence of controlling shareholders. By extending VD, potential opportunistic behaviours by controlling managers and shareholders (which attempt to hide detailed information useful for all stakeholders) could be limited. CG regulators should oblige listed companies to increase the minimum number of board members and the number of non-executive members to gain the desired increase in VD and transparency and to protect shareholders. Saudi listed companies are advised to increase their board members to the maximum number specified by CMA to strengthen transparency and disclosure practices, and thereby attract foreign investment in the stock market and contribute to achieving the Saudi Vision objectives. It is expected that listed companies with stronger CG, reflected in a larger board with a majority of non-executive director members, are able to resolve crisis problems and thus improve VD.

The study has a number of limitations. First, the sample 
is too small for any generalisations to be applied to all listed companies. Second, the VD data were collected from annual reports only, and other sources like companies' websites and press releases were not taken into account. This represents an opportunity for future studies. Finally, this study covers only certain listed nonfinancial companies in the materials sector; other nonfinancial materials and other listed companies were not accounted for in the sample.

Other avenues for future studies can investigate the effect of the same independent variables on mandatory disclosure in Saudi Arabia, or investigate the effects of the other independent variables covered in this study on voluntary disclosure. Further, investigations of other nonfinancial and financial sectors can generate interesting results. Therefore, it is recommended that the sample be increased in a future study to include all nonfinancial sector companies. Also, when gathering information related to voluntary disclosure, it is recommended to consult companies' websites and all relevant press releases.

\section{REFERENCES}

[1] Abdel-Fattah, T. M. H. (2008). Voluntary disclosure practices in emerging capital markets: the case of Egypt. (Phd thesis). Durham University, Durham.

[2] Abdelqader, M., Nimer, K., \& Darwish, T. K. (2021). IFRS compliance in GCC countries: do corporate governance mechanisms make a difference? International Journal of Disclosure and Governance, 1-15. Retrieved from https://link.springer.com/article/10.1057/s41310-021-0012 3-3

[3] Ahmed, F. (2021). Corporate boards, audit committees and voluntary disclosure: a case analysis on Bangladeshi listed companies. European Journal of Business and Management Research, 6(2), 153-155.

[4] Akhtaruddin, M., Hossain, M. A., Hossain, M., \& Yao, L. (2009). Corporate governance and voluntary disclosure in corporate annual reports of Malaysian listed firms. Journal of Applied Management Accounting Research, 7(1), 1-19.

[5] Al-Bassam, W. M., Ntim, C. G., Opong, K. K., \& Downs, Y. (2018). Corporate boards and ownership structure as antecedents of corporate governance disclosure in Saudi Arabian publicly listed corporations. Business \& Society, 57(2), 335-377.

[6] Al-Ghamdi, M., \& Rhodes, M. (2015). Family ownership, corporate governance and performance: evidence from Saudi Arabia. International Journal of Economics and Finance, 7(2), 78-89.

[7] Al-Janadi, Y., Rahman, R. A., \& Omar, N. H. (2013). Corporate governance mechanisms and voluntary disclosure in Saudi Arabia. Research Journal of Finance and Accounting, (4)/4, 25-35.

[8] Al-Moataz, E., \& Hussainey, K. (2013). Determinants of corporate governance disclosure in Saudi corporations. Journal of King Abdulaziz University: Economics \& Administration, 27(2), 411-430.

[9] Al-Nimer, M. (2019). Effect of corporate governance rules on voluntary disclosure in Jordanian corporations listed with the Amman stock exchange (ASE):(an empirical study). Studies in Business \& Economics, 14(1).

[10] Al-Shammari, B., \& Al-Sultan, W. (2010). Corporate governance and voluntary disclosure in Kuwait. International Journal of Disclosure and Governance, 7(3), 262-280.

[11] Al - Razeen, A., \& Karbhari, Y. (2004). Interaction between compulsory and voluntary disclosure in Saudi Arabian corporate annual reports. Managerial Auditing Journal, (19)/3, 351-60.

[12] Albassam, W. (2014). Corporate governance, voluntary disclosure and financial performance: ban empirical analysis of Saudi listed firms using a mixed-methods research design. PhD Thesis. University of Glasgow. Glasgow.

[13] Albassam, W. M., \& Ntim, C. G. (2017). The effect of Islamic values on voluntary corporate governance disclosure. Journal of Islamic Accounting and Business Research, 8(2), 182-202.

[14] Alsaeed, K. (2006). The association between firm - specific characteristics and disclosure. Managerial Auditing Journal. (5), 476-96

[15] Alturki, K. H. (2014). Voluntary disclosure by Saudi companies. Research Journal of Finance and Accounting, 5(20), 77-94.

[16] Baek, H. Y., Johnson, D. R., \& Kim, J. W. (2009). Managerial ownership, corporate governance, and voluntary disclosure. Journal of Business and Economic Studies, 15(2), 44.

[17] Bhattacharyya, A. K. (2012). Financial accounting for business managers (3rd ed.). New Delhi: PHI Learning Pvt. Ltd.

[18] Bonazzi, L., \& Islam, S. M. (2007). Agency theory and corporate governance: a study of the effectiveness of board in their monitoring of the CEO. Journal of modelling in management, 2(1), 7-23.

[19] Bouaziz, M. Z. (2014). Corporate governance and voluntary financial disclosure by Canadian listed firms. Management Review: An International Journal, 9(1), 44-69.

[20] Bryman, A., \& Cramer, D. (2002). Quantitative data analysis with SPSS release 10 for Windows: a guide for social scientists: Routledge.

[21] Buallay, A., Hamdan, A., \& Zureigat, Q. (2017). Corporate governance and firm performance: evidence from Saudi Arabia. Australasian Accounting, Business and Finance Journal, 11(1), 78-98.

[22] Chau, G., \& Gray, S. (2002). Ownership structure and corporate voluntary disclosure in Hong Kong and Singapore. The International Journal of Accounting, 37(2), 247-265.

[23] Cheng, E. C., \& Courtenay, S. M. (2006). Board 
composition, regulatory regime and voluntary disclosure. The International Journal of Accounting, 41(3), 262-289.

[24] Cho, S.-Y., Kang, P. K., Lee, C., \& Park, C. (2020). Financial reporting conservatism and voluntary CSR disclosure. Accounting Horizons, 34(2), 63-82.

[25] Christopher, J. (2010). Corporate governance-a multi-theoretical approach to recognizing the wider influencing forces impacting on organizations. Critical perspectives on accounting, 21(8), 683-695.

[26] Clemente, A. G., \& Labat, B. (2009). Corporate governance mechanisms and voluntary disclosure-the role of independent directors in the boards of listed Spanish firms. Journal of Financial Economics, (5), 243-270.

[27] CMA. (2017). Corporate governance regulations. Capital Market Authortiy, Riyadh, KSA.

[28] Collett, P., \& Hrasky, S. (2005). Voluntary disclosure of corporate governance practices by listed Australian companies. Corporate Governance: An International Review, 13(2), 188-196.

[29] Cormier, D., Ledoux, M. J., Magnan, M., \& Aerts, W. (2010). Corporate governance and information asymmetry between managers and investors. Corporate Governance: The International Journal of Business in Society, (10)/5, 574-589.

[30] Craswell, A. T., \& Taylor, S. L. (1992). Discretionary disclosure of reserves by oil and gas companies: an economic analysis. Journal of Business Finance \& Accounting, 19(2), 295-308.

[31] Desta, I., Kaihula, B. P., \& Kifle, T. (2019). Industry characteristics and voluntary disclosure in private mining and manufacturing firms in Tanzania. The Journal of Developing Areas, 53(3), 141-154.

[32] Di Pietra, R., Grambovas, C. A., Raonic, I., \& Riccaboni, A. (2008). The effects of board size and 'busy'directors on the market value of Italian companies. Journal of management $\&$ governance, 12(1), 73-91.

[33] Donnelly, R., \& Mulcahy, M. (2008). Board structure, ownership, and voluntary disclosure in Ireland. Corporate Governance: An International Review, 16(5), 416-429.

[34] Eisenhardt, K. M. (1989). Agency theory: an assessment and review. Academy of management review, 14(1), 57-74.

[35] El-Deeb, M. S., Halim, Y. T., \& Elbayoumi, A. F. (2021). Disclosure tone, corporate governance and firm value: evidence from Egypt. Asia-Pacific Journal of Accounting \& Economics, 1-22.

[36] Elfeky, M., \& Nasiri, A. (2017). The Determinants of voluntary disclosure in emerging markets: The case of Egypt. Journal of Poverty, Investment and Development, $36(7), 1-12$.

[37] Eng, L. L., \& Mak, Y. T. (2003). Corporate governance and voluntary disclosure. Journal of Accounting and Public Policy, 22(4), 325-345.

[38] Fama, E. F., \& Jensen, M. C. (1983). Separation of ownership and control. The journal of law and Economics, 26(2), 301-325.
[39] Frenkel, S., Guttman, I., \& Kremer, I. (2020). The effect of exogenous information on voluntary disclosure and market quality. Journal of financial economics, 138(1), 176-192.

[40] Gad, J. (2020). The association between disclosures on control system over financial reporting and mechanisms of corporate governance: Empirical evidence from Germany and Poland. International Journal of Management and Economics, 56(4), 351-369.

[41] Ghazali, N. A. M., \& Weetman, P. (2006). Perpetuating traditional influences: Voluntary disclosure in Malaysia following the economic crisis. Journal of International Accounting, Auditing and Taxation, 15(2), 226-248.

[42] Gunawan, H., \& Lina, E. O. (2015). Mandatory and voluntary disclosure of annual report on investor reaction. International Journal of Economics and Financial Issues, 5, 311-314.

[43] Habbash, M., Hussainey, K., \& Awad, A. E. (2016). The determinants of voluntary disclosure in Saudi Arabia: an empirical study. International Journal of Accounting, Auditing and Performance Evaluation, 12(3), 213-236.

[44] Haniffa, R., \& Hudaib, M. (2007). Locating audit expectations gap within a cultural context: The case of Saudi Arabia. Journal of International Accounting, Auditing and Taxation, 16(2), 179-206.

[45] Hashed, A., \& Almaqtari, F. (2021). The impact of corporate governance mechanisms and IFRS on earning management in Saudi Arabia. Accounting, 7(1), 207-224.

[46] Hussainey, K., \& Al-Nodel, A. (2008). Corporate governance online reporting by Saudi listed companies. Research in Accounting in Emerging Economies, (8), 39-64.

[47] Jensen, M. C., \& Meckling, W. H. (1976). Theory of the firm: managerial behavior, agency costs and ownership structure. Journal of financial economics, 3(4), 305-360.

[48] Ke, R., Li, M., \& Zhang, Y. (2020). Directors' informational role in corporate voluntary disclosure: an analysis of directors from related industries. Contemporary Accounting Research, 37(1), 392-418.

[49] Khanchel El Mehdi, I. (2007). Empirical evidence on corporate governance and corporate performance in Tunisia. Corporate Governance: An International Review, 15(6), 1429-1441.

[50] Khanifah, K., Hardiningsih, P., Darmaryantiko, A., IRYANTIK, I., \& Udin, U. (2020). The effect of corporate governance disclosure on banking performance: Empirical evidence from Iran, Saudi Arabia and Malaysia. The Journal of Asian Finance, Economics, and Business, 7(3), 41-51.

[51] Kristandl, G., \& Bontis, N. (2007). The impact of voluntary disclosure on cost of equity capital estimates in a temporal setting. Journal of Intellectual Capital, (8)/4, 577-594.

[52] Kumar, K. (2007). Drivers of corporate voluntary disclosure a framework and empirical evidence from Italy and the United States Accounting, Auditing \& Accountability Journal, 20(2), 269-296.

[53] Laksmana, I. (2008). Corporate board governance and voluntary disclosure of executive compensation practices. 
Contemporary Accounting Research, 25(4), 1147-1182.

[54] Lambert, R. A. (2001). Contracting theory and accounting. Journal of accounting and economics, 32(1-3), 3-87.

[55] Larmou, S., \& Vafeas, N. (2010). The relation between board size and firm performance in firms with a history of poor operating performance. Journal of management \& governance, 14(1), 61-85.

[56] Lee, Y., \& Lee, S. (2014). Interaction effects between ownership concentration and leverage on firm performance. Management Review: an International Journal, 9(1), 70-106.

[57] Li, H., \& Qi, A. (2008). Impact of corporate governance on voluntary disclosure in Chinese listed companies. Corporate Ownership and Control, 5(2), 360-366.

[58] Mallin, C. (2007). Corporate governance (2nd ed.): Oxford University Press.

[59] Mansulu, A. (2021). Corporate governance and voluntary disclosure practices in Czech Republic. Acta Universitatis Agriculturae et Silviculturae Mendelianae Brunensis, 69(1), $111-125$.

[60] Mariq, S. M. (2009). An assessment of voluntary disclosure in the annual reports of Saudi joint stock companies. Economics and Administration, 23(1), 131-174.

[61] Maskati, M. M. A., \& Hamdan, A. M. M. (2017). Corporate governance and voluntary disclosure: evidence from Bahrain. International Journal of Economics and Accounting, 8(1), 1-28.

[62] Masum, M. H., Latiff, A. R. A., \& Osman, M. N. H. (2020). Ownership structure and corporate voluntary disclosures in transition economy. The Journal of Asian Finance, Economics, and Business, 7(10), 601-611.

[63] Matoussi, H., \& Chakroun, R. (2008). Board composition, ownership structure and voluntary disclosure in annual reports: Evidence from Tunisia. Laboratoire Interdisciplinaire de Gestion Universite-Entreprise (LIGUE), 1-28.

[64] Meek, G. K., Roberts, C. B., \& Gray, S. J. (1995). Factors influencing voluntary annual report disclosures by US, UK and continental European multinational corporations. Journal of International Business Studies, 26(3), 555-572.

[65] OECD. (2004). OECD principles of corporate governance. Paris: OECD Publications.

[66] Onakoya, A. B., Ofoegbu, D. I., \& Fasanya, I. O. (2012). Corporate governance and bank performance: A pooled study of selected banks in Nigeria. European Scientific Journal, 8(28), 155-164.

[67] Owais, W. O. (2021). Voluntary disclosure and its role in promoting confidence in the financial reports of services companies enlisted in securities commission. Academy of Strategic Management Journal 20(S1).

[68] Patelli, L., \& Prencipe, A. (2007). The relationship between voluntary disclosure and independent directors in the presence of a dominant shareholder. European Accounting Review, 16(1), 5-33.

[69] Peasnell, K. V., Pope, P. F., \& Young, S. (2005). Board monitoring and earnings management: do outside directors influence abnormal accruals? Journal of Business Finance \& Accounting, 32(7 - 8), 1311-1346.

[70] Robertson, C. J., Diyab, A. A., \& Al-Kahtani, A. (2013). A cross-national analysis of perceptions of corporate governance principles. International Business Review, $22(1), 315-325$

[71] Rosenstein, S., \& Wyatt, J. G. (1990). Outside directors, board independence, and shareholder wealth. Journal of financial economics, 26(2), 175-191.

[72] Saha, R., \& Kabra, K. (2020). Corporate governance and voluntary disclosure: a synthesis of empirical studies. Business Perspectives and Research, 8(2) 117-138.

[73] Sallehuddin, M. R. (2016). The impact of corporate governance on voluntary disclosure among public-listed companies in Malaysia. e-Academia Journal UiTMT, 5(2), 48-57.

[74] Schuster, P., \& O'Connell, V. (2006). The trend toward voluntary corporate disclosures. Management Accounting Quarterly, 7(2), 1.

[75] Shapiro, S. P. (2005). Agency theory. Annual Review of Sociology, 31, 263-284.

[76] Solomon, J., \& Solomon, A. (2004). Corporate governance and accountability. England: John Wiley \& Sons Ltd.

[77] Tian, Y., \& Chen, J. (2009). Concept of voluntary information disclosure and a review of relevant studies. International Journal of Economics and Finance, 1(2), 55-59.

[78] Tsang, A., Xie, F., \& Xin, X. (2019). Foreign institutional investors and corporate voluntary disclosure around the world. The Accounting Review, 94(5), 319-348.

[79] Ullah, A., Shah, S., \& Asif, M. (2018). The impact of corporate governance on voluntary disclosure: evidence from Pakistan. City University Research Journal, 8(2), 155-167.

[80] Wadesango, N., Charity, M., Blessing, M., \& Haufiku, H. (2020). The effects of corporate governance on financial performance of commercial banks in a turbulent economic environment. Acta Universitatis Danubius. Economica, 16(4).

[81] Zahra, S. A., \& Pearce, J. A. (1989). Boards of directors and corporate financial performance: A review and integrative model. Journal of management, 15(2), 291-334.

[82] Zayoud, K., Al-Othman, M., \& Issa, R. A. (2011). Voluntary disclosure level in the annual reports of the Syrian Joint Stock companies listed on Damascus securities exchange. Tishreen University Journal for Research \& Scientific Studies-Economics, 27-44. 